\title{
Comparative Study on the Biochemical Character of HGGs from Trophoblastic Tumor and Normal Pregnancy
}

\author{
Natsuto MOGHIZUKI, Yoshihiko ASHIDAKA, \\ Yasumasa TOKURA and Shimpei TOJO \\ Department of Obstetrics and Gynecology, School of Medicine, Kobe University, Kobe, Japan
}

(Director : Professor Shimpei Tojo, M.D.)

Recent endocrinological knowledge on proteohormone producing tumor has drawn attention to the comparison of the hormone secreted from normal cells with that from tumor cells. But, reports on a comparative study of the biochemical character of gonadotropins from normal chorionic tissue and chorionic tumor tissue are still scarce.

In the present study, HCGs from chorionic tumor and normal pregnancy were purified by Sephadex gelfiltration and ion-exchange cellulose column chromatography. For a strict comparison between these HCGs, identical procedures were employed for the purification of every preparation. Urinary gonadotropin was extracted by alcohol precipitation method and Kaolin-Adsorption method. Biological activity of HCG was assayed by ovarian weight method referring to 2nd international standard HCG. Immunological activity was assayed by hemoagglutination inhibition reaction.

1) Comparison of HCGs on CM-G column chromatography.

Both HCGs were eluted in two fractions on Sephadex gelfiltration. The retarded fractions were biologically inactive but the unretarded fractions were biologically active. These unretarded fractions were further separated into non-adsorbed part and adsorbed part on GM-G column chromatography. Only the non-adsorbed part was biologically active in both HCGs.

This is an interesting difference from the pituitary gonadotropins, since biological activity of pituitary gonadotropin is observed in the adsorbed part but not in the non-adsorbed part when it is fractionated on GM-G column chromatography.

2) Comparison of HCGs on DEAE-C column chromatography.

In both HCGs, biological activity was present in adsorbed fraction but not in nonadsorbed fraction. In other words, the biologically active protein is adsorbed on DEAE-C but not adsorbed on CM-C. The activity was as high as 20,000 IU/mg in the preparation from normal pregnancy and 8,000 IU/mg from chorionic tumor patient.

When HCG activity of adsorbed protein was seen in connection with conductivity, most of the HGG activity from normal pregnancy was eluted between 3.0 and $5.0 \mathrm{~m}$ mho, but that from chorionic tumor was eluted in two parts at more than 5.0 and less than $2.0 \mathrm{~m}$ mho but it was not eluted at the conductivity between 3.0 and $5.0 \mathrm{~m}$ mho at which normal HCG activity was eluted. On the other hand, when such biologically active adsorbed 
protein was subjected to linear gradient elution, the amount of eluted protein from normal pregnancy showed a monophasic peak, whereas, the amount of protein from chorionic HCG was much larger at very low and high conductivity at which a very little amount of the protein from normal pregnancy was eluted.

These facts suggest that chorionic tumor HCG is composed of two kinds of protein (acidic and basic) with complexed constitution which differs from that of normal HCG, and they further suggest the difference of the biochemical character of both HCGs.

Recovery of biological activity and the amount of protein were calculated as follows. In normal pregnancy, recovery ratio of protein was $42.5 \%$ by GM-G column chromatography and $9.8 \%$ by the final DEAE-C column chromatography as to the fraction having $20,000 \mathrm{IU} / \mathrm{mg}$ of biological activity, the recovery ratio of protein was $2.2 \%$ and that of biological activity was about 50\%. In chorionic tumor HCG, the recovery of protein was $30.6 \%$ by CM-G column chromatography and $4.3 \%$ by DEAE-C column chromatography, but final recovery of biological activity was $42 \%$.

In both HCGs, immunological activity was high in the fractions with low conductivity. In such fractions of normal pregnancy, both activities were almost parallel, but they were not so in chorionic tumor HCG. And, in general, the fractions having high biological activity were eluted at high conductivity and showed very low immunological activity. Such tendency of dissociation of biological activity and immunological activity was more evident in chorionic tumor HCG, and HCG with biological activity and HCG with immunological activity were eluted at different conductivity. Further, comparison of HCGs from normal pregnancy and chorionic tumor at every step of purification also revealed that in both HCGs, HCG with biological activity and HCG with immunological activity were eluted at a different conductivity. The HCGs from normal pregnancy and chorionic tumor were also different in their potency of being adsorbed by ion-exchange cellulose.

As a conclusion all the above findings strongly suggest that the molecular structure of HCG from normal pregancy differs from that of HCG from trophoblastic tumor.

(pp. 482 485) 


\title{
腫瘍性 HCG と正常䋐毛性 HCG の精製とその性状の比較
}

\author{
神戸大学医学部産科婦人科学教室（主任 東条伸平教授） \\ 望月真 人, 足高善 彦 \\ 都食康正, 東条伸平
}

(昭和 43 年 4 月 10 日受付)

紱毛性腫瘍の正確な診断及び予後の钼察の為に, 腫痬性 HCG と正常絨毛性 HCG の性状を比較解 明する事を目的とし，同一の精製過程で両 HGG の純化を行ない，特に conductivity と生物活性及 び免疫活性の相関から両 HCG を比較したところ, 活性分画の溶出される conductivity は両 HCG で 異り， cellulose に対する吸着態度にも明らかな差を認めた。乙の事から腫煌性 HCG は正常絨毛性 HCG とかなりの性状の差があり, 両者を同一視する事は出来ない.

\section{緒論}

最近, 蛋白系ホルモンを分泌する腫瘍に関する内分泌学的知見が報告されはじめ, 正常細胞から分泌され るホルモンと腫瘍細胞から分泌されるそれとの比較検討成績が多くの興味を惹くようになり, とりわけ AGTH や TSH 産生腫暍については, その生物学的, 免度学的, あるいは生化学的性状がかなり詳細に追 究されているのに反し，研究の歴史が古いのにも拘らず，正常絨毛性ゴナドトロピンと腫痬性ゴナドトロピ ンの生化学的性状を比較検討した報告は少ない，我々は従来よりてれらの HCG について，生化学的性質 の比較検討を行なつて来たが，今回，両 HGG を同一方法で純化精製し，高い specific activity を持つた HCG を採取し得, 純化精製過程における両者の態度について比較検討を行ない, 興味ある成績を得たので その概要を報告する。

\section{I 実験材料並びに実験方法}

\section{A. 実験材料}

正常妊娠初期妊婦尿よりアルーコール沈澱法で抽出された粗 HCG $(2130 \mathrm{IU} / \mathrm{mg}$, 友田製薬)，および紱 腫㭧者尿より, Bradbury 法一松島変法で抽出し, 乾燥粉抹の状態でアンプルに封入し， 2 年間冷凍保存さ れていた粗 HCG を使用した。

\section{B. 実験方法}

1. 生物活性の測定

生物学的活性は標準品に 2nd international standard HCG を用い, 幼若ラット卵策重量法 $(\lambda=0.176)$ で測定した。 なお HCG の生物学的活性は精製過程での各段階每に測定した。

\section{2. 免疫活性の測定}

免疫活性の測定は $0.5 \mathrm{IU} / \mathrm{ml}$ の感度を持つ様に調整された赤血球凝集阻止反応によつた。各精製過程で の免废活性測定は生物活性測定の場合と同様である.

\section{3. 精製方法}

我々の行なつた精製方法の詳細は別飞報告してあるので1)それを参照されたい. cellulose column から の蛋白質の溶出は linear gradient elution 法で行ない, 溶出分画の蛋白濃度は O.D. $280 \mathrm{~m} \mu$ で測定し た。 また溶出分画の conductivity (milli mhos) は conductivity meter type CDM $2 \mathrm{~d}$ にて各溶出量每 に測定した. 


\section{II 実 験 成 樍}

\section{A CM-G chromato. における両者の比較}

Sephadex gel filtration による粗 HCG の unretarded fraction は GM-G chromato. で非吸着蛋白と 吸着蛋白とに分離した。絨腫 HCG および正常妊娠初期 HCG の CM-G 吸着蛋白は $1 \mathrm{M}-\mathrm{NH}_{4}$ Ac buffer (pH 7.0,22.0 m•mhos) で linear gradient 法で溶出すると, Fig. 1 の如く, O.D. $280 \mathrm{~m} \mu$ の上からほぼ 3 つの分画に分離される。溶出分画の conductivity から見ると 3 分画は両者ともに一致しているが, 正常 妊娠 HCG では第 1 分画, 絨腫 HGG では第 2 分画の占める割合が高かつた. なお生物活性は両者とも GM-C 吸着蛋白のいずれの分画にも認められず，非吸着蛋白部分のみにてれを認めた。

B DEAE-G chromato. における両者の比較

生物活性を示す GM-G 非吸着蛋白はさらに DEAE-C chromato. で非吸着部分と吸着部分に分離するが, このうち生物活性を示すのは吸着部分のみである (Fig. 2).

\section{1. 蛋白濃度と conductivity の相関について}

吸着部分の溶出 pattern は, Fig. 3 に示してあるように絨腫 HCG では conductivity 8 以上の㙁類濃 度の高い分画にも溶出蛋白を認めるが, conductivity 8 以下の分画について両者を比較すると, 同じよに

Fig. 1. Relationship between O.D. and conductivity

Chromatography of HCG on CM.G

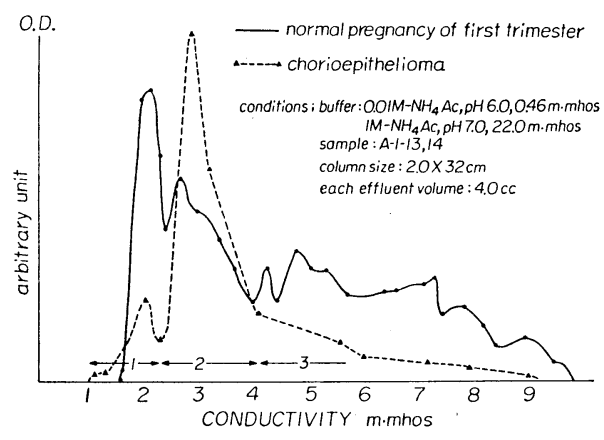

Fig. 2. Ghromatography of purified HCG from chorioepithelioma on DEAE-G

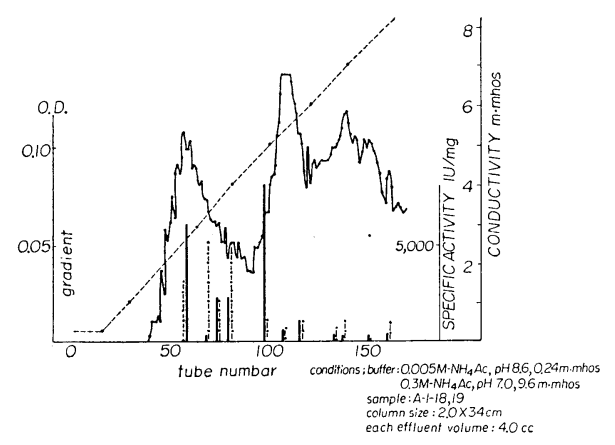

Fig. 3. Relationship between O.D. and conductivity

hr omatography of HCG on DEAE-C

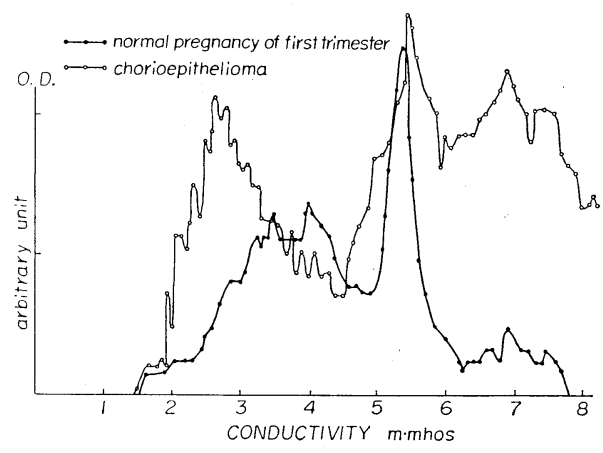

Fig. 4. Relationship between specific activity and conductivity

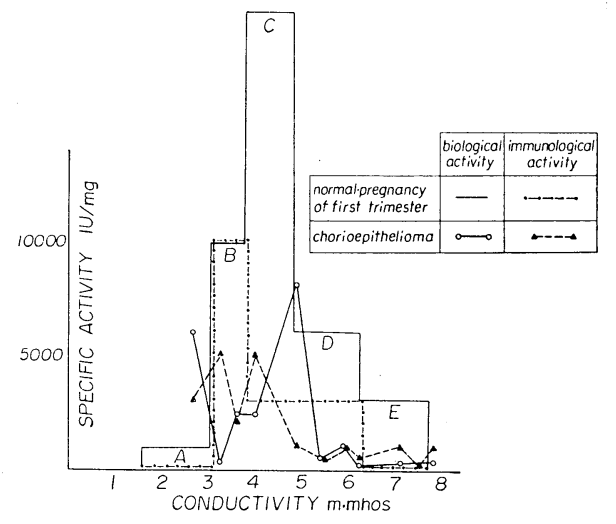


ほぼ 3 分画に分れている。しかしながら conductivity からみると，第 2 , 第 3 分画はほぼ一致しているの に反し, 第 1 分画は正常妊娠 HGG と絊腫 HCG では一致していない.

\section{HGG 活性と conductivity の相関について}

正常妊娠 HCG の溶出 pattern を Fig. 4 のように5 分画に分けて夫々の HCG 活性を測定すると, 生 物活性は B 分画で $10,000 \mathrm{IU} / \mathrm{mg}, \mathrm{C}$ 分画で $20,000 \mathrm{IU} / \mathrm{mg}, \mathrm{D}$ 分画で $6,000 \mathrm{IU} / \mathrm{mg}$ の值を得たが，免疫活性 は B 分画で $10,000 \mathrm{IU} / \mathrm{mg}, \mathrm{C}$ 分画で $3,000 \mathrm{IU} / \mathrm{mg}, \mathrm{D}$ 分画で $3,000 \mathrm{IU} / \mathrm{mg}$ となつた。主に生物活性を認める 分画の conductivity は 3.0-4.5 m・mhos の範囲にある.

絨腫 HCG では生物活性は $2.66 \mathrm{~m} \cdot \mathrm{mhos}$ の分画で $6,000 \mathrm{IU} / \mathrm{mg}, 4.92 \mathrm{~m} \cdot \mathrm{mhos}$ の分画で $8,000 \mathrm{IU} / \mathrm{mg}$ で あつたが, その他の分画では低值で, 明らかな 2 峰性を示し, 一方免疫活性は $3.26 \mathrm{~m} \cdot \mathrm{mhos}$ と $4.00 \mathrm{~m} \cdot \mathrm{mhos}$ でその活性を認め, 両活性は明らかに解離している.

\section{3. 生物活性ならびに蛋白質の回収率}

正常妊娠 HCG の場合, GM-G chromato. を行なつた段階での活性分画の蛋白回収率は42.5\%になり， DEAE-C chromato. では $9.8 \%$ そ減少した. なお $20,000 \mathrm{IU} / \mathrm{mg}$ の生物活性をもつたC分画の蛋白量は 2.2 \%であつた。 最終段階の生物活性の回収率は $42.0 \%$ であつた。

䋐腫 HCG の場合, CM-C chromato. での蛋白回収率は 30.6\%, DEAE-C chromato. では conductivity 8 以下の活性分画について $4.3 \%$ であつた.

\section{III 考按}

腫瘍細胞から分必される蛋白系ホルモンと, 本来の内分泌細胞から分泌されるホルモンが同一であるか不 かという問題の解明は, そのホルモン産生腫瘍担体の予後を分泌されるホルモンの動態から推察する場合に は重大な意味をもつ，とりわけ異所性ホルモン分泌腫瘍の代表である ACTH 産生腫痬については比較的 詳細な検討がなされており, 現在のとてろ腫痬より抽出された ACTH は下垂体性 ACTH と生物学的作 用, 生化学的, 免疫学的特性についてほとんど差が認められないという報告が多い2).とてろがゴナドトロ ピンと同様に glycoprotein である TSH を分泌する腫煬については, その TSH は, Condliffe, 望月ら ${ }^{3)}$ の研究によれば, 生理的 TSH とアミノ酸組成, 糖成分等の面で差がみられるという.

とてろで婦人に発生する悪性度の高いホルモン産生腫惕としては絨毛性腫痬があり, てのものの HCG 分 泌に関する研究は古くから活発に行なわれているが, 本症の診断, ならびにその予後の観察に用いられるゴ ナドトロピン検出法の成績を, 正常妊娠 HCG の概念から判断してよいかどうかという大きな問題があり, ての為にも当然 HCG の性格を比較検討してみる必要が生じる.

とてろで蛋白精製の手段として専ら使用されるイオン交換クロマトグラフィーでは, deamidation によ つて conformational change を惹起する恐れがあるので), 我々はての様な変化を起とさないで不安定な 物質の分離精製に最適といわれる molecular sieving method を用いて，正常 HCG ならびそ腫痬性 HCG の性状の比较㰸討 を行ない，1）䄉毛性腫演患者尿中 HCG には，正常妊婦尿中 HCG に認められない $\mathrm{Kd}$ 值の小さな, 即ち分子量の大きな HGG が存在するとと，2）生物活性にも差があり，その性状は奇胎 では FSH 的であり, 䋐腫ではより LH 的性格の強いてと，3）腫愃性 HCG では生物活性と免疫活性と がより解離するてと，4）腫痬性 HCG は正常妊娠 HCG よりもより basic な蛋白体から構成されている が, 䋐腫においては生物活性をあまり示さない acidic な蛋白体の contamination が非常に強い事を従来

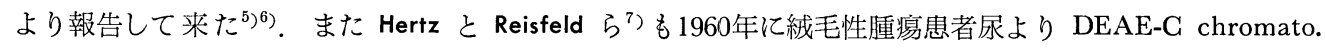
によつて精製した HGG と，Got らの精製した正常妊婦尿中 HCG についてその物理化学的性状を比較し， 両者の間にかなりの差がみられる事を発表しているがての報告は両者の精製方法が異つている為に, 精製手 段の異なる両 HCG を比較するとと自体に多くの問題を含んでいるものと考えられる．そこで今回我々は 両者の粗 HCG を同一条件で純化精製を試み, 精製過程におけるその態度から両者を比較検討した。

HCG の純化には一般に DEAE-G chromato. が主として使用され，GM-C は用いられていない。 その主 
な理由は, 等電点の低い HGG が弱酸性カチオン交換セルローズである GM-G に吸着しない為であると 考えられる. 我々が Sephadex gel filtration, DEAE-G chromato. に加えて GM-C chromato. を採用した のは，GM-G に吸着する夾雑蛋白体を HCG から除外する為である。 また cellulose に吸着した蛋白体を 溶出させる方法として，一般には step weise elution 法が用いられている。乙の方法は操作が簡単で再現性 に富んでいるが, 一定モル濃度の溶媒で種々の conductivity の吸着能を持つ蛋白体を溶出させる為に, 溶 出された蛋白体が hornogeneity でないと共に, イオン交換体に吸着する蛋白固有の吸着能の比較が出来な い. そこで我々はその溶出 pattern から conductivity と活性の関係を詳細に検討する為に linear gradient elution 法を採用し，また操作中に deamidation を起さない様に考えて終始一貫して $\mathrm{NH}_{4} \mathrm{Ac}$ buffer を使用した。

一般に弤娠中には negative feed back mechanism によつて下垂体性ゴナドトロピンの分泌は抑制され ているものと考えられているが, steroid hormone 分泌の少い縅毛性腫瘍の場合, 下垂体性ゴナドトロピン の contamination も否定はできない. Condliffe $\left.ら^{8}\right)$ の下垂体性ゴナドトロピンの精製に関する報告によ ると，下垂体性ゴナドトロピンは GM-G に吸着されており，それからみると我々の条件下では，下垂体性 ゴナドトロピンは CM-G に吸着するものと考えられる.しかしながら CM-G 财着蛋白体に HCG 活性を 確認できなかつた事は, 少くとも我々の精製している腫痬性 HCG には下垂体性ゴナドトロピンの contamination は否定されるものと思われるが, 粗 HCG に contamination していた吸着蛋白体は, 正常妊娠 HGG と腫瘍性 HCG とで異つており, 後者はとくに acidic な蛋白体が多い.

次に DEAE-G chromato. では両 HCG とも非吸着蛋白体には HCG 活性を認めなかつたが, 吸着蛋白 体の HCG 活性と conductivity の関係からみると, 正常 HGG では大体 conductivity 3.0-5.0m・mhos でほとんどの HCG 活性が溶出されたのに反し, 絨腫 HCG では conductivity 2.0 以下 5.0 と上とに解 離して HGG 活性が溶出され, 正常 HGG の溶出される分画には溶出されていないという全く異つた吸着 態度を示した．との事は絨腫 HGG を構成する蛋白体は basic なものと acidic なものとから成り，正常 妊娠 HCG にみられない複雑な構成を示すものと考えられるとともに, 両者の生化学的性状の差を示唆す るものと思われる. 免疫活性はいずれの HCG にわいても conductivity の低いとてろで溶出される HGG 分画に一致して高值であるが, conductivity の高い所で溶出され，しかも高度の HCG 活性をもつ分画で はその活性が非常に低く，生物活性と明らかに解離している。この様な傾向は絨腫 HCG で著明であり, 生物活性を示す HCG と免疫活性を示す HCG とは conductvity が異つている.

現在我々は正常妊娠 HCG から赤血球凝集阻止反応で免疫活性を示さない高度の HGG 活性 $(24,000 \mathrm{IU} /$ mg）の HGG を採取してのものの生化学的性状の検討を行なつているが後日報告したい.

\section{結 語}

各種精製過程で腫演性 HGG と正常 HGG を比較検討した結果, 両者の間では生物活性, 免疫活性, そ の溶出される conductivity が異つており, イオン交換セルロースに対する吸着能にも差のある事が判明し た.との事は少くとも両 HGG の生化学的性状にかなりの差があのととを示唆するものと考えられる.

\section{参 考 文 献}

1）望月真人, 足高善彦, 都倉康正, 東条伸平 : 日産婦誌, $20: 550$, (1968).

2) 山路徹 : 小之臨, 15 : 791, (1967). 3 3) CONDLIFFE, P.G. and MOChIZUKI, M. : Endocrinology, (in press) 4) CONDLIFFE, P.G. and MOCHIZUKI, M. : Current Topics in Thyroid Research, (1966), 415, Academic Press, N.Y. 5) 植田安雄, 他：産婦の世思, $18: 230$, (1966). 6) 望月真人, 他： 産婦の世思, $18: 526$, (1966). 7 7) REISFELD, R.A. and HERTZ, R. : Biochim. Biophys. Acta, $43: 540$, (1960). $\quad$ 8) PARLOW, A.F., CONDLIFFE, P.G., REIGHERT, L.E. and WILHELMI, A. E. : Endocrinology, $76: 27$, (1965). 